\title{
Pekerjaan, Nonpekerjaan, dan Psikologi Sosial sebagai Penyebab Kelelahan Operator Alat Berat di Industi Pertambangan Batu Bara
}

\author{
Work-related, Non-work related, and Social Psychology as Causes of Heavy \\ Equipment Operators Fatigue in Coal Mining Industry
}

\author{
Indri Hapsari Susilowati, Ridwan Zahdi Syaaf, Chandra Satrya, Hendra, Baiduri
}

Departemen Keselamatan dan Kesehatan Kerja Fakultas Kesehatan Masyarakat Universitas Indonesia

\begin{abstract}
Abstrak
Kelelahan merupakan salah satu faktor penyebab kecelakaan transportasi, ditandai dengan menurunnya kinerja fisik dan mental yang mengakibatkan kurangnya kewaspadaan karena rasa kantuk. Penelitian ini bertujuan untuk mengetahui faktor risiko dan faktor pendukung kelelahan pada operator alat berat. Penelitian dilakukan pada operator alat berat di 3 tambang batubara di Kalimantan ( 2 area di Kalimantan Timur dan 1 area di Kalimantan Selatan), melibatkan 353 operator alat berat yang bekerja dengan 3 sif. Hasilnya menunjukkan bahwa keluhan kelelahan semakin tinggi dengan meningkatnya usia, lama kerja, dan kerja pada sif 3 (malam hari). Kelelahan paling banyak dirasakan oleh operator dump truck (bagian hauling) yang dipengaruhi oleh faktor-faktor pekerjaan (postur saat bekerja, faktor variasi pekerjaan, beban kerja dan vigilance) dan faktor-faktor bukan pekerjaan (kondisi medan atau area tambang yang berisiko, penerangan yang kurang pada malam hari, dan rute yang selalu berubah). Faktor lainnya berkaitan dengan masalah sosial-psikologis, baik yang berhubungan dengan pekerjaan maupun lingkungan kerja, seperti waktu istirahat, standar gaji yang belum memadai, pengaturan jadwal cuti yang sering tidak jelas, dan masalah karier. Disimpulkan, secara umum kelelahan meningkat dengan bertambahnya usia dan lama kerja, dengan kelelahan yang lebih besar pada pekerja sif 3 . Umumnya, penurunan waktu reaksi pekerja sif malam lebih besar daripada waktu reaksi pekerja sif siang.

Kata kunci: Kecelakaan transportasi, kelelahan, operator alat berat
\end{abstract}

\section{Abstract}

Fatigue is one of the causes of transportation accidents, characterized by reduced physical and mental performance resulting in reduced alertness due to drowsiness. The present study was to determine the risk factors and contributing factors of fatigue suffered by heavy equipment operators. The study was conducted at three coal mining sites in Kalimantan (2 areas in East Kalimantan and 1 area in South Kalimantan) involving 353 heavy equipment operators who work in shifts. It was found that fatigue complaint is higher by older age, longer work, and work at shift 3 (night time). The fatigue is mostly complained by dump truck (hauling part) operators which was influenced by work-related factors (work posture, job variety, workload, vigilance) and non-work related factors (terrain or mine risk area, lack of lighting at night, and route track which is always changed). Another factors related with socio-psychological factors, either related with job or working environment, such as adequacy of rest time, remuneration system, leave system, and insecure career. It is concluded that in general the fatigues were increased as the worker ages were older and longer duration of work, with higher fatigues were suffered at shift 3. Generally, reduced reaction time among shift 3 workers is higher than that those of daytime shift. Keywords: Transport accident, fatigue, heavy equipment operators

\section{Pendahuluan}

Kelelahan pengemudi merupakan suatu faktor risiko kecelakaan dalam transportasi. ${ }^{1}$ Penelitian mengenai kecelakaan transportasi di Selandia Baru antara tahun 2002 dan 2004 menunjukkan bahwa dari 134 kecelakaan fatal, $11 \%$ disebabkan oleh faktor kelelahan dan dari 1.703 cedera akibat kecelakaan, $6 \%$ disebabkan oleh kelelahan pada operator. ${ }^{1,2}$

Kelelahan pada pengemudi mengakibatkan menurunnya daya konsentrasi, timbulnya rasa kantuk, lambatnya bereaksi, kelelahan pada mata, kejenuhan, menurunnya perhatian, tertidur sesaat, dan keluar dari jalur yang seharusnya. ${ }^{3}$ Penelitian mengenai kelelahan di Australia pada tahun 2000 menunjukkan bahwa 45\% dari operator kendaraan berat jarak jauh mengaku mengalami

Alamat Korespondensi: Indri Hapsari Susilowati, Departemen Keselamatan dan Kesehatan Kerja FKM Universitas Indonesia, Kampus Baru UI Depok Gd. C Lt. 2 16424, Hp.081255564412,e-mail: indri.susilowati@gmail.com 
kelelahan pada akhir waktu kerja mereka dan mempunyai kontribusi $15 \%$ terhadap kecelakaan. ${ }^{4-8}$ Di samping itu, penelitian terhadap kecelakaan transportasi di kota Makassar menunjukkan bahwa $65,8 \%$ dari pengemudi yang mengalami kelelahan berat dan $40,5 \%$ dari pengemudi yang mengalami kelelahan ringan mengalami kecelakaan di lalu lintas. ${ }^{9}$ Jelas bahwa kelelahan dapat dilihat sebagai penyebab kecelakaan dan dapat pula dilihat sebagai suatu akibat dari berbagai faktor. Seringkali masalah di luar pekerjaan (psikososial) dan juga hal-hal lain menjadi pemicu terjadinya kelelahan. ${ }^{10} \mathrm{Di}$ antara faktorfaktor kelelahan yang diteliti menyangkut hal-hal yang terkait langsung dengan pekerjaan, yang tidak terkait dengan pekerjaan, dan faktor khusus lainnya. ${ }^{11}$

Di Indonesia, kelelahan pada operator alat berat yang mengakibatkan kecelakaan transportasi di jalur tambang belum banyak diteliti. Penelitian ini bertujuan untuk mengetahui faktor risiko dan faktor pendukung terjadinya kelelahan pada operator alat berat.

\section{Metode}

Data penelitian diperoleh dengan teknik pengisian kuesioner, wawancara berstruktur, dan observasi di lapangan, dan pengukuran waktu reaksi pada saat sebelum dan setelah bekerja. Populasi penelitian adalah seluruh operator alat berat perusahaan kontraktor tambang dari tiga lokasi tambang batubara di Kalimantan (2 area di Kalimantan Timur dan 1 area di Kalimantan Selatan) pada Tahun 2007. Besar sampel diperoleh dengan menggunakan metode purposive proposional sampling sehingga dari populasi tersebut diambil secara acak 353 operator alat berat sebagai responden yang secara rinci diperoleh dari perusahaan di area 1 sebanyak 90 $(25,5 \%)$ responden, area 2 sebanyak $141(39,9 \%)$ responden dan di area 3 sebanyak $122(34,6 \%)$ responden. Selain itu, dikumpulkan pula data sekunder mengenai data karyawan, jenis kendaraan yang digunakan, rekam medik, data kehadiran karyawan, sistem sif kerja, kebijakan manajemen dan peraturan lain yang terkait dengan kelelahan, program pencegahan kecelakaan dan kelelahan dari unit K3, dan accident dan injury report. Data yang diperoleh selanjutnya diolah secara kuantitatif dan kualitatif untuk memperoleh gambaran tingkat kelelahan yang terjadi serta faktor risiko yang berkaitan dengan pekerjaan, yang tidak berkaitan dengan pekerjaan, dan faktor khusus yang berkaitan dengan timbulnya kelelahan.

\section{Hasil}

Karakteristik operator alat berat yang bekerja di tiga tambang batu bara di Kalimantan ( 2 area di Kalimantan Timur dan 1 area di Kalimantan Selatan) tercantum dalam Tabel 1. Dalam tabel ini tertera data mengenai unit kerja, pola giliran waktu bekerja (sif), lama kerja, tempat tinggal, dan jenis kendaraan berat yang dioperasikan.
Tabel 1. Karaktersitik Operator Alat Berat

\begin{tabular}{llll}
\hline Karakteristik Operator & Kategori & n & $\%$ \\
\hline Usia & $\leq 25$ tahun & 106 & 30,0 \\
& $26-35$ tahun & 116 & 32,9 \\
Unit kerja & 35 tahun & 131 & 37,1 \\
& Operation & 219 & 62,1 \\
& Hauling & 78 & 22,1 \\
& Mekanik & 35 & 9,9 \\
& Tyre & 11 & 3,1 \\
Warehouse & 4 & 1,1 \\
Pola kerja & Fuelman & 5 & 1,4 \\
\multirow{4}{*}{ Lama kerja } & Lainnya & 1 & 0,3 \\
& 2 sif & 121 & 34,3 \\
& 3 sif & 232 & 65,7 \\
& $<1$ tahun & 33 & 9,3 \\
1 & 3 tahun & 147 & 41,6 \\
Jenis kendaraan & 5 - 10 tahun & 26 & 7,4 \\
& $>10$ tahun & 49 & 13,9 \\
& Mess karyawan & 98 & 27,8 \\
& Luar mess karyawan & 158 & 44,8 \\
& Dump truck & 195 & 55,2 \\
& Alat-alat berat & 223 & 63,2 \\
& Dolly & 58 & 16,4 \\
& Lainnya & 65 & 18,4 \\
& & 7 & 2,0 \\
\hline
\end{tabular}

Tabel 2. Faktor Risiko yang Terkait dengan Pekerjaan Operator Alat Berat

\begin{tabular}{llll}
\hline Faktor Risiko & Kategori & $\mathbf{n}$ & $\%$ \\
\hline Beban kerja & Berat & 221 & 62,6 \\
& Sedang & 127 & 36 \\
& Ringan & 5 & 1,4 \\
Variasi kerja & Tinggi & 26 & 7,4 \\
& Sedang & 315 & 89,2 \\
Postur saat bekerja & Tidak bervariasi & 12 & 3,4 \\
& Berisiko tinggi & 325 & 92,1 \\
& Berisiko sedang & 17 & 4,8 \\
& Berisiko rendah & 8 & 2,3 \\
Vigilance & Tidak berisiko & 3 & 0,8 \\
& Tinggi & 150 & 42,5 \\
& Rendah & 193 & 54,7 \\
& Tidak & 10 & 2,8 \\
\hline
\end{tabular}

Faktor risiko kelelahan yang terkait dengan pekerjaan (work related factor) operator alat berat tercantum dalam Tabel 2. Tabel ini menampilkan data mengenai beban kerja, variasi kerja, postur tubuh saat bekerja, dan tingkat kewaspadaan/vigilance. Faktor vigilance adalah hal-hal yang menyebabkan pekerja harus selalu dalam kondisi konsentrasi secara terus-menerus.

Faktor risiko yang tidak terkait dengan pekerjaan dan berhubungan dengan indikasi kelelahan adalah aktivitas lain saat bekerja dan pengaruh lingkungan. Sebagian besar responden yang terindikasi mengalami kelelahan berat menyatakan bahwa mereka melakukan pekerjaan lain saat bekerja seperti makan, minum, dan salat. Waktu yang diberikan kepada operator untuk istirahat dalam satu shift umumnya adalah 30 menit. Dengan waktu ini, sebagian besar responden $(75,9 \%)$ mengatakan bahwa waktu istirahat yang diberikan sudah cukup (Tabel 3). 
Tabel 3. Faktor Risiko yang Tidak Terkait dengan Pekerjaan Operator Alat Berat

\begin{tabular}{llll}
\hline Faktor Risiko & Kategori & $\mathbf{n}$ & $\%$ \\
\hline \multirow{2}{*}{ Waktu istirahat } & Memadai & 268 & 75,9 \\
\multirow{2}{*}{ Aktivitas lain saat bekerja } & Kurang memadai & 85 & 24,1 \\
& Ada & 300 & 85 \\
Lingkungan & Tidak ada & 53 & 15 \\
\multirow{2}{*}{ Supervisi dan manajemen } & Mengganggu & 325 & 92,1 \\
& Tidak mengganggu & 28 & 7,9 \\
& Mendukung & 276 & 78,2 \\
& Kurang mendukung & 77 & 21,8 \\
\hline
\end{tabular}

\section{Pembahasan}

\section{Faktor Risiko Kelelahan}

Indikasi tingkat kelelahan diukur dengan menggunakan kuesioner dan pengukuran waktu reaksi, serta pengamatan langsung dari kondisi pengemudi. Beberapa indikasi kelelahan pada operator yang dilihat yaitu timbulnya rasa kantuk, tertidur sesaat, lambatnya bereaksi, kelelahan pada mata, kejenuhan, menurunnya perhatian dan konsentrasi, seperti salah atau keluar dari jalur.

Dari penelitian ini, didapatkan bahwa proporsi terbesar responden yang terindikasi mengalami kelelahan berat terjadi pada responden yang berusia $>35$ tahun, memiliki lama kerja $1-3$ tahun, tinggal di luar mes karyawan, dan mengoperasikan dump truck. Dilihat dari faktor usia, responden yang berusia $>35$ tahun banyak terindikasi mengalami kelelahan berat. Hal itu terjadi karena secara fisiologis orang yang berusia di atas 30 tahun telah mengalami penurunan kapasitas fisik yang dapat diperberat oleh aktivitas kerja yang melebihi kapasitasnya. ${ }^{12}$

Aktivitas pertambangan berjalan selama 24 jam sehingga perlu sif kerja malam hari. ${ }^{13}$ Berdasarkan hasil observasi dan reaction time, responden yang banyak terindikasi kelelahan berat adalah mereka yang bekerja pada sif 3 (pukul 22.00 - 06.00). Reaksi mereka setelah bekerja menjadi semakin lambat dibandingkan dengan pekerja pada sif lainnya. Sedangkan, sif 2 dan 3 tidak menunjukkan perbedaan yang menonjol dari hasil reaction time sebelum dan sesudah bekerja sebagai indikasi kelelahan.

Efek kerja sif malam secara fisiologis adalah terganggunya siklus sikardi dan meningkatnya gangguan tidur. ${ }^{4}$ Jika hal itu terjadi dalam jangka waktu lama maka akan mengganggu fisiologis tubuh dan gaya hidup seperti kebiasaan tidur dan pola makan yang buruk. ${ }^{13}$ Jika fisiologis dan pola hidup pekerja terganggu maka akan terjadi gangguan kesehatan secara umum, keselamatan, kinerja, dan pastisipasi sosial.

Secara rinci, gangguan akibat bekerja pada sif malam dapat berupa gangguan respons biologi, masalah kesehatan, perubahan gaya hidup, dan masalah sosial. ${ }^{14-16}$ Gangguan respons biologi yaitu gangguan siklus sikardi, dimana siklus tubuh dalam 24 jam terganggu, seperti gangguan jam tidur. Pada malam hari siklus tubuh harusnya pemulihan energi kembali dengan istirahat atau tidur tetapi diharuskan tidak tidur karena bekerja. Tidak setiap waktu merupakan saat yang kondusif untuk tidur, ada waktu yang disebut 'forbidden zones' untuk tidur, yaitu antara pukul 8 pagi sampai pukul 12 siang dan pukul 5 sore sampai pukul 9 malam. Hal ini akan memengaruhi masalah kesehatan yaitu meningkatnya kerentanan tubuh terhadap flu dan kebiasan makan. Dalam jangka waktu lama, keadaan akan menyebabkan gangguan yang lebih parah seperti gangguan saluran pencernaan (radang usus besar, konstipasi, indigestion, food craving, dan ulser peptik), gangguan pada neuropsiko (kelelahan kronik, kecemasan, depresi), dan gangguan pada jantung dan pembuluh darah (hipertensi, penyakit jantung iskemik). Sif malam akan merubah gaya hidup seseorang, yaitu banyaknya keluhan dan gangguan kualitas dan ketidakcukupan tidur, waktu untuk olah raga, nutrisi buruk, konsumsi alkohol, dan ketergantungan lainnya. Pada akhirnya, masalah sosial akan muncul, seperti ketidakseimbangan antara waktu kerja, keluarga dan lingkungan sosial yang dapat menyebabkan stres dan kurangnya partisipasi dalam komunitas.

Selain usia, perbedaan masa kerja juga berdampak pada kelelahan. Responden yang banyak terindikasi mengalami kelelahan berat adalah mereka dengan lama kerja 1 - 3 tahun. Berdasarkan hasil wawancara, responden yang lama kerjanya 1 - 3 tahun belum memiliki pengaturan waktu istirahat yang baik. Setelah pulang kerja, mereka tidak langsung beristirahat, tetapi masih melakukan aktivitas lain seperti jalan-jalan atau bersosialisasi di lingkungannya yang kadang-kadang berlangsung hingga larut malam. Aktivitas ini seringkali mengurangi waktu istirahat mereka. Indikasi kelelahan berat juga dirasakan oleh responden yang tinggal di luar mess karyawan. Sebabnya, mereka membutuhkan waktu yang lebih lama untuk sampai ke rumah dan beristirahat. Begitu pula pada saat memulai kerja, mereka membutuhkan waktu yang lebih lama untuk sampai ke tempat kerja. Kondisi tersebut menyebabkan waktu istirahat mereka lebih singkat dibandingkan dengan responden yang tinggal di mess karyawan.

Berdasarkan hasil analisis data kuesioner, responden yang banyak terindikasi mengalami kelelahan berat adalah mereka yang bekerja di bagian operation, terutama pada operator dump truck. Hal tersebut disebabkan karena selama mengoperasikan alat berat hanya dilakukan oleh satu orang operator sehingga memang dibutuhkan usaha yang cukup besar, medan transportasi yang cukup berat pada unit kerja operasi, dan tidak ada waktu selang atau istirahat yang cukup dibandingkan dengan operator bagian hauling yang masih dapat beristirahat saat loading maupun unloading sehingga operator alat berat di 
bagian operation harus selalu waspada dan konsentrasi penuh selama mengoperasikan unitnya.

Indikasi kelelahan yang dialami oleh responden unit operation memperlihatkan bahwa mereka yang mengoperasikan dump truck mempunyai persentase tertinggi untuk mengalami kelelahan. Hal tersebut sebenarnya lebih disebabkan karena sebaran responden yang didominasi oleh operator dump truck dibandingkan dengan operator alat-alat berat dan operator dolly. Fakta di lapangan menunjukkan bahwa operator alat-alat berat mempunyai risiko yang lebih besar mengalami kelelahan karena faktor target waktu, kondisi medan, dan posisi duduk dalam waktu yang lama dalam melaksanakan pekerjaan dilapangan operator alat-alat berat, khususnya yang melakukan loading ke dump truck, mempunyai waktu kerja yang padat dan cenderung tanpa istirahat, sedangkan operator dump truck dan operator dolly mempunyai waktu yang agak senggang, khususnya apabila terjadi antrian untuk loading maupun waktu unloading bagi operator dolly. Waktu menunggu untuk mendapat giliran digunakan oleh operator untuk beristirahat meskipun ia tetap berada dalam truk.

\section{Faktor Risiko yang Terkait dengan Pekerjaan}

Indikasi kelelahan responden lebih banyak didominasi oleh faktor yang terkait dengan pekerjaan, terutama faktor beban kerja dan postur kerja, sedangkan faktor dominan kelelahan yang tidak terkait dengan pekerjaan adalah faktor lingkungan. Persentase terbesar faktor risiko yang dialami responden adalah beban kerja yang berat, postur berisiko tinggi saat bekerja, variasi kerja yang tergolong sedang, dan faktor vigilance yang rendah.

Beban kerja berat yang dialami operator disebabkan oleh beberapa hal seperti target waktu, kondisi medan, dan posisi duduk dalam waktu yang lama. ${ }^{17}$ Wawancara terhadap beberapa operator dump truck memperlihatkan bahwa mengendarai dump truck adalah pekerjaan dengan beban sedang, sedangkan yang dianggap berat adalah tanggung jawab operator terhadap kendaraan yang dioperasikan. Namun, para operator alat-alat berat umumnya menyatakan bahwa mengendarai alat-alat berat memang tergolong berat karena harus bekerja terus-menerus untuk melayani dump truck dan dolly. Pada operator dolly, beban kerja yang berat disebabkan oleh duduk yang terlalu lama, masalah antrian kendaraan, dan sikap yang harus selalu waspada.

Sebagian besar responden yang terindikasi mengalami kelelahan berat dialami oleh mereka yang mempunyai beban kerja yang berat, sedangkan responden yang terindikasi mengalami kelelahan sedang banyak dialami oleh mereka dengan beban kerja sedang. Hal tersebut sangat alamiah karena tingkat beban kerja seseorang akan berpengaruh secara langsung terhadap tingkat kelelahan yang dialaminya.
Variasi kerja responden diketahui paling banyak tergolong sedang $(89,2 \%)$. Berdasarkan pengamatan dan wawancara, jenis pekerjaan yang dilakukan oleh responden, khususnya operator, tidak banyak bervariasi. Operator alat berat selalu berada di dalam unit selama bekerja, dengan posisi duduk, dan jalur operasi yang sama. Tetapi dari hasil pengamatan banyak responden yang mengalami kelelahan berat dan sedang. Hal ini dikarenakan bosan dan kejenuhan yang dialami oleh responden. Variasi pekerjaan yang semakin banyak menyebabkan semakin banyak pula tanggung jawabnya, dan hal ini akan menyebabkan kelelahan semakin mungkin muncul. Hal ini bertentangan dengan hasil riset pada penelitian ini. 18

Sebagian besar responden mempunyai postur kerja yang berisiko tinggi. Postur kerja yang berisiko disebabkan oleh posisi kerja yang tidak ergonomis. Risiko tinggi postur kerja pada operator, baik dump truck, alat-alat berat, maupun dolly, lebih disebabkan oleh posisi duduk dalam waktu yang lama ketika melakukan pekerjaan. Khusus pada operator alat-alat berat, kelelahan juga disebabkan oleh ruang kabin kendaraaan yang tidak nyaman.

Postur kerja yang berisiko akan berdampak terhadap kelelahan kerja. Hal tersebut menunjukkan bahwa postur kerja merupakan masalah utama yang berkaitan dengan indikasi kelelahan pada pekerja. Postur kerja yang statis pada saat menyetir akan memengaruhi kelelahan pada otot rangka, terlebih lagi jika hal ini dilakukan dalam jangka waktu yang lama dalam kabin sopir. ${ }^{19}$

Vigilance adalah hal-hal yang menyebabkan pekerja harus selalu dalam kondisi berkonsentrasi secara terusmenerus. ${ }^{20}$ Vigilance kerja yang tinggi umumnya dialami oleh operator dolly. Operator ini harus selalu waspada dan berkonsentrasi dalam bekerja. Mengemudikan dolly dengan medan yang jauh, lurus, dan menjenuhkan mengharuskan operator selalu dalam konsentrasi tinggi saat bekerja. Di samping hal-hal tersebut, jalur yang dilalui kendaraan juga digunakan oleh masyarakat umum sehingga menimbulkan risiko lain selama bekerja. Hal serupa juga terjadi pada operator dump truck dan alatalat berat, khususnya bila bekerja pada malam hari. Di samping medan yang berisiko, konsentrasi tinggi secara terus-menerus juga disebabkan oleh kurangnya penerangan di lokasi kerja.

\section{Faktor Risiko yang Tidak Terkait dengan Pekerjaan}

Faktor dominan yang tidak terkait dengan pekerjaan yang berdampak pada indikasi kelelalahan adalah faktor lingkungan kerja seperti udara yang berdebu, udara yang panas, suara bising, dan tempat kerja atau alat kerja yang bergetar. Sebagian besar responden $(92,1 \%)$ pada tabel 3 yang terindikasi mengalami kelelahan berat merasakan bahwa mereka terganggu oleh lingkungan kerja. Pada 
siang hari khususnya, udara yang panas dan berdebu merupakan hal yang memperberat pekerjaan. Hal tersebut juga diperburuk oleh ketersediaan air minum yang kadang-kadang kurang memadai. Khusus untuk operator dolly, tingginya aktivitas masyarakat di sepanjang jalur yang dilalui juga dianggap mengganggu proses kerja. Kemampuan menyetir akan dipengaruhi dengan kondisi lingkungan, terutama terkait dengan jarak dan luas pandangan mata di jalan. Jika jalannya tidak terlihat jelas karena debu, akan mengganggu kemampuan menyetir dan dapat menimbulkan kecelakaan di jalan raya. ${ }^{21}$ Bila dilihat dari faktor manajemen seperti supervisi, perhatian, dan dukungan manajemen, sebagian besar responden merasa bahwa manajemen cukup memberikan dukungan terhadap pekerjaan mereka.

\section{Faktor Risiko Lain (Sosial-Psikologis)}

Faktor risiko lain adalah waktu istirahat, supervisi, dan manajemen. Meskipun waktu istirahat yang ada telah dirasakan memadai dan supervisi serta manajemen sangat mendukung, sebagian besar responden tetap terindikasi mengalami kelelahan berat. Selain itu, faktor lain yang menjadi indikasi kelelahan yang dirasakan oleh pekerja antara lain standar gaji yang belum memadai, pengaturan jadwal cuti yang sering tidak jelas, dan masalah karir dan kenaikan golongan yang kurang jelas parameternya.

\section{Kesimpulan}

Gejala kelelahan yang dialami operator alat-alat berat di tambang batubara sudah terindikasi, namun masih tidak terlalu tinggi. Peningkatan kelelahan berhubungan dengan meningkatnya faktor usia dan lama bekerja di perusahaan. Kelelahan yang lebih besar dijumpai pada pola kerja tiga sif. Pada umumnya, penurunan waktu reaksi pekerja sif malam lebih besar dibandingkan dengan waktu reaksi pekerja sif siang. Penurunan waktu reaksi pada sif pagi diperkirakan terkait dengan aktivitas di rumah atau di mess sebelumnya. Kelelahan yang dirasakan oleh operator dump truck dipengaruhi oleh kondisi medan tambang yang berisiko, seperti penerangan pada malam hari yang kurang, dan rute yang selalu berubah. Kelelahan ini juga dipengaruhi oleh kondisi jalan yang lurus, dekat dengan penduduk, dan adanya operator dari subkontraktor lain. Pada operator alat berat, bekerja terus-menerus tanpa waktu jeda yang cukup merupakan faktor yang berkaitan dengan kejadian kelelahan.

\section{Ucapan Terima Kasih}

Terima kasih kepada Lia Amelia, Wahyu Aditya, Oka Bujiana, Wenni Sriastuti yang membantu dalam pengumpulan data. Terima kasih juga untuk disampaikan untuk divisi K3 PT X yang mengizinkan site tambangnya digunakan sebagai area penelitian ini.

\section{Daftar Pustaka}

1. Australian Safety and Compensation Council. Work-related fatigue: summary of recent indicative research 2006. Canberra: Australian Government; 2006.

2. Baker A, Ferguson S. Work design, fatigue and sleep: a resource document for the minerals industry. Australia: Minerals Council of Australia; 2004.

3. Beaulieu JK. The issues of fatigue and working time in the road transport sector. Geneva: International Labour Office; 2005.

4. Klauer SG. The effects of fatigue on driver performance for single and team long-haul truck drivers. Proceeddings of the second International Driving Symposium on Human Factors in Driver Assessment, Training and Vehicle Design; 2003. p. 143-7.

5. Savage M, Pipkins D. The effect of rest periods on hand fatigue and productivity. Journal of Industrial Technology. 2006; 22(3): 1-6.

6. De Vries J, Michielsen HJ, Van Heck GL. Assessment of fatigue among working people: a comparison of six questionnaires. USA: Occupational Environment Medicine; 2003.

7. United States, Department of Health and Human Services. Overtime findings on illnesses, injuries, and health behaviours. Washington: Center for Disease Control and Prevention National Institute for Occupational Safety and Health; 2004.

8. Ehrlich SS, Friedman L, Richter ED, Working conditions and fatigue in professional truck drivers at Israeli ports. Injury Prevention Journal. 2005; 11: 110-4.

9. Russeng SR. Faktor risiko terjadinya kecelakaan bus trayek TorajaMakassar tahun 2003-2007. Jurnal Media Kesehatan Masyarakat Indonesia. 2008: 4(2): 93-5.

10. Dittner AJ, Wessely SC, Brown RG. The assessment of fatigue: a practical guide for clinicians and researchers. Journal of Psychosomatic Research. 2004; 56: 157-70.

11. Sherry P. Final report on assessment of fatigue in train and engine employees of the union pacific railroad in the San Antonio area [Project Report]. Denver: University of Denver: 2005.

12. Hilderbrandt VH, Bongers PM, Van Dijk FJH, Kemper HCG, Dul J. Dutch musculoskeletal questionnaire: description and basic qualities. Ergonomics [serial on internet]. 2001; 44 (12): 1038-55 [cited 2011 Dec 10]. Available from: www.ncbi.nlm.nih.gov/pubmed/11780727.

13. Kinetic Centre for Human Sciences \& Simon Folkard Associates Limited. The development of a fatigue/risk index for shiftworkers. England: Health and Safety Execituve; 2006.

14. Roads and Traffic Authority. Driver fatigue: problem definition and countermeasure summary. Sydney: Road and Traffic Authority; 2001.

15. Savage M, Pipkins D. The effect of rest periods on hand fatigue and productivity. Journal of Industrial Technology. 2006; 22(3): 1-6.

16. Sherman K. An evaluation of fatigue and performance changes during intermittent overhead work [thesis]. Blakssburg: Virginia Polytechnic Institute; 2003.

17. Human Performance Research Group. NASA Task Load Index v.1.0 computerized version. California: Blackwell Publishing; 2004.

18. Winwood PC, Winefield AH, Lushington K. Work-related fatigue and recovery: the contribution of age, domestic responsibilities and shift work. Journal of Advanced Nursing. 2006; 56(4): 438-49.

19. Magnusson ML, Pope MH. A review of the biomechanics and epidemi- 
Kesmas, Jurnal Kesehatan Masyarakat Nasional Vol. 8, No. 2, September 2013

ology of working postures. Journal of Sound and Vibration. 1998; 215(4): 965-6.

20. Lamond N, Drew D, Roach GD. Fatigue assessment in the field: validation of a hand-held electronic psychomotor vigilance task. Aviation,
Space and Environmental Medicine Journal. 2005; 76(5): 486-9.

21. Thiffault P, Bergeron J. Monotony of road environment and driver fatigue: a simulator study. Accident Analysis and Prevention Journal. 2003; 35: 381-91. 